\title{
Dunaliella salina as marine microalga highly tolerant to but a poor remover of cadmium
}

\author{
S. Folgar, E. Torres, M. Pérez-Rama, A. Cid, C. Herrero, J. Abalde ${ }^{1}$
}

Journal of Hazardous Materials, Volume 165, Issues 1-3, 15 June 2009, Pages 486493

Received 14 February 2008, Revised 9 June 2008, Accepted 6 October 2008, Available online 14 October 2008

DOI: 10.1016/j.jhazmat.2008.10.010

\begin{abstract}
Cadmium tolerance and removal in the marine microalga Dunaliella salina were studied in cultures exposed to different metal concentrations $\left(5-120 \mathrm{mg} \mathrm{Cd} \mathrm{l}^{-1}\right)$ for $96 \mathrm{~h}$. This microalga can be included in the group of microalgal species most tolerant to cadmium due to the high value of EC50 that it possesses ( $48.9 \mathrm{mg} \mathrm{Cd} \mathrm{l}^{-1}$ at $96 \mathrm{~h}$ of culture). The greater percentage of cadmium removed was obtained in cultures exposed to $5 \mathrm{mg} \mathrm{Cd} \mathrm{l}^{-1}$ at $96 \mathrm{~h}$, but removing only $11.3 \%$ of the added cadmium. In all cultures, the quantity of cadmium removed intracellularly was much lower than the bioadsorbed quantity and it was proportional to the sulfhydryl group levels. Both the Freundlich and Langmuir adsorption models were suitable for describing the short-term biosorption of cadmium by living cells of $D$. salina.
\end{abstract}

\section{Keywords}

Microalga; Metal; Toxicity; Removal; Sulfhydryl groups

\section{Introduction}

Owing to the rapid expansion of industrialization, metals are among the polluting agents more intensely studied. Their study is due to the toxicity that they exert on the organisms and ecosystems when a certain threshold of bioavailability is exceeded, and also due to their persistence in the environment. For these reasons, biotoxicity tests and maximum tolerable limits are critical for evaluating the potential impact of these pollutants in the aquatic ecosystems. Metals are dumped to environment from numerous and diverse anthropogenic sources and they are considered dangerous for the aquatic life due to their prolonged permanence in sediments and their tendency to bioaccumulate in alive-cells and tissues.

\footnotetext{
${ }^{1}$ Departamento de Biología Celular y Molecular, Laboratorio de Microbiología, Facultad de Ciencias, Universidade da Coruña, Alejandro de la Sota $n^{\circ}$ 1, 15008 La Coruña, Spain
} 
The deterioration of the aquatic systems for diverse pollutants is currently a major problem, and for this reason is necessary to find suitable methods to study their toxicity. The most common studies of ecotoxicity for following aquatic pollutants in the short-term are the test of deadliness in fish, which have been criticized recently for economic, logistic and ethical reasons [1]. One of the alternatives that are proposed is the use of the lowest organisms in the aquatic chain, such as bacteria and microalgae. The microalgae are among the most important microorganisms in the ecosystems because they are primary producers. They are used widely in aquiculture, agriculture and in the fodder industry. Their rapid growth and their ubiquity in environments make them good indicators of the health of the ecosystems, since, as other microorganisms, they are going to be affected directly by the pollutants.

Microalgae are microorganisms frequently used for evaluating the toxicity of polluting agents present in the sea [2]. The use of microalgae is well studied and standardized [3] and [4], with microalgal growth being the most used assay, because it reflects the metabolism of the cell [5]. Diverse active and passive mechanisms for the metal incorporation to microalgae were proposed. The cellular walls of microalgae have a great capacity to bind metals [6]. This fact is of a special importance since the marine microalgae constitute the first link of the marine trophic chain and thus, they can transfer metal contaminants to higher levels. For this reason, bioaccumulation must be considered in the studies of toxicity with microalgae, especially when the microalgal biomass is used to predict the removal of metals from natural ecosystems [7].

Although cadmium is recognized as one of the most toxic metals [8] its concentration in oceanic surfaces is very low (an average of $0.0014 \mathrm{nmol} \mathrm{kg}^{-1}$ ) [9]. However, it is used in many industrial processes (production of television tube phosphors, alloy preparation, metal plating, nuclear reactor shields and rods, pigments, stabilizers, batteries, etc.) and the waste streams from these processes end up contaminating the aquatic environments [9] and [10]. Such contamination has created the need to develop techniques for its removal from the environment. The phenomenon of removing metal ions by microorganism has been explored successfully. However, little information has been available on the accumulation of metals by microalgal biomass. To maximize the potential application of microalgae to bioremediation of metals, it is necessary to understand why metals are toxic, how microalgae defend against them and the properties of the bioaccumulation process in this biomass.

One of the most common microalgae responses to cadmium stress is the synthesis of low molecular weight sulfhydryl compounds (such as phytochelatins). Cadmium forms complexes with these thiols preventing its toxicity. This reaction is considered to play an important role in metal homeostasis and metal detoxification [11], [12], [13] and [14]. For this reason, is important to study the ability of a microalga to synthesize sulfhydryl compounds because this synthesis affects both its capacity of tolerance and cadmium bioaccumulation.

The marine microalga Dunaliella salina (Chlorophyceae) is a phytoplanktonic specie that has a great distribution in the marine ecosystems. This supralittoral species often predominates in blooms of natural populations [15]. Also, it is a specie widely used in laboratory cultures and in toxicity assays to evaluate the effects of industrial effluents [16]. 
The purpose of this study was to evaluate some aspects of the cadmium interaction with $D$. salina. The effect of cadmium on growth, the ability of this microalga to remove cadmium and the production of sulfhydryl-group-rich compounds as a mechanism of defence to the toxicity of this metal were investigated.

\section{Materials and methods}

\subsection{Culture conditions}

The marine microalga $D$. salina was cultured for $96 \mathrm{~h}$ in natural enriched seawater media. The seawater was passed through a $0.45 \mu \mathrm{m}$-pore Millipore filter and a charcoal column to eliminate organic chelating substances and subsequently sterilized at $121^{\circ} \mathrm{C}$ for $20 \mathrm{~min}$. The assays were carried out in this natural seawater with the addition of inorganic nutrients [17] but without EDTA and Tris. The salinity of seawater was $35 \%$ and the initial $\mathrm{pH}$ of the culture was 7.8 . A stock solution of cadmium was prepared by dilution of $\mathrm{CdCl}_{2}$ in Milli-Q water to a final concentration of $10 \mathrm{~g} \mathrm{l}^{-1}$ of $\mathrm{Cd}$. For the experiment, appropriate volume of the stock solution was added to the seawater to obtain final cadmium concentrations of $5,10,20,30,40,60,80,100$ and $120 \mathrm{mg} \mathrm{Cd} \mathrm{l}^{-1}$.

The cultures were carried out in 1-I glass bottles (PYREX). The bottles were previously rinsed with nitric acid and then rinsed several times with Milli-Q water. Inside these bottles, the enriched seawater and a suitable volume of the stock solution of cadmium were placed with

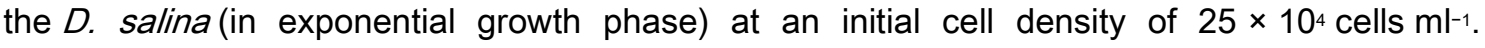
Cultures without metal were also included as control. All cultures were maintained at $18 \pm 1{ }^{\circ} \mathrm{C}$ with an irradiance of $68.25 \mu \mathrm{E} \mathrm{m}^{-2} \mathrm{~s}^{-1}$ using cool fluorescent light and a dark:light cycle of 12:12 h. Natural sterile air was constantly bubbled at a flow rate of $101 \mathrm{~min}^{-1}$. Each experiment was carried out in triplicate and the results were evaluated with the average of these three replicates.

\subsection{Growth}

Growth of the microalgal cultures was measured daily, counting culture aliquots in a Neubauer haemocytometer chamber after fixation with Lugol. The degree of growth inhibition by cadmium in $D$. salinacells was measured during $96 \mathrm{~h}$ of culture. For that, the EC50 for growth (metal concentration which reduces the population growth to $50 \%$ of the control) was calculated using a log dose-response curve. Analysis of the data was conducted by applying a nonlinear regression to log metal concentration vs. the mean percent reduction in cellular density at $96 \mathrm{~h}$ of culture using SigmaPlot 9.01 (Systat Software, Inc.). The EC50 was calculated from the regression equation. Weibull equation of four parameters was chosen for its good fitness[4].

\subsection{Determination of cadmium removed}


The method used to evaluate the cadmium removed by the cells of $D$. salina was a modification of the method used by Stauber and Florence [18].

\subsubsection{Total cadmium removed}

Total cadmium removed in cells was determined by filtration of $25 \mathrm{ml}$ aliquots from each culture through two superposed 1.2- $\mu \mathrm{m}$ MF Millipore filters. The cadmium levels were measured in both filters using the lower filter as blank.

\subsubsection{Cadmium removed intracellularly}

For the determination of the cadmium removed intracellularly, aliquots of $25 \mathrm{ml}$ of each culture were centrifuged at $3500 \times g$ during $15 \mathrm{~min}$, and the pellet was resuspended during $20 \mathrm{~min}$ in $25 \mathrm{ml}$ of a solution of $0.02 \mathrm{M}$ EDTA dissolved in seawater. EDTAs function is to eliminate the cadmium adsorbed onto the cell surface, allowing only the intracellular cadmium fraction to be measured. Then, the culture was centrifuged for $15 \mathrm{~min}$ at $3500 \times \mathrm{g}$ and the pellet was washed with seawater and centrifuged again at $3500 \times g$ during $15 \mathrm{~min}$ (this procedure of wash was repeated two times).

\subsubsection{Bioadsorbed cadmium}

The determination of bioadsorbed cadmium onto the cell surface was calculated by subtracting the intracellular cadmium concentration from the total cadmium removed (bioadsorbed cadmium $=$ total cadmium - intracellular cadmium) .

\subsubsection{Measurement of cadmium}

Each one of the filters from the determination of total cadmium removed and the pellets from the determination of cadmium removed intracellularly were separately digested for $24 \mathrm{~h}$ in a mixture of $1 \mathrm{ml}$ of $15 \mathrm{M} \mathrm{HNO}_{3}$ and $0.5 \mathrm{ml}$ of $11.6 \mathrm{M} \mathrm{HClO}_{4}$. Digested samples were brought to final volume of $5 \mathrm{ml}$ with Milli-Q water. The quantity of cadmium present in each of the samples was measured by ICP-MS using VG Elemental Plasma Quad 2 ICP-MS System (Element 2, Thermofinnigan, Germany). The cadmium removed percentage (\%) was calculated on the basis of cadmium added to each culture. All the previous determinations were made daily for $96 \mathrm{~h}$.

\subsection{Biosorption isotherms}

Two sorption isotherms were considered to identify the isotherm that describes better the biosorption of cadmium by the biomass of $D$. salina . The linearized forms of the Langmuir and Freundlich equations were used for analysis and they are given as $\frac{1}{q_{\mathrm{e}}}=\frac{1}{q_{\max }}+\frac{1}{q_{\max } b C_{\mathrm{e}}}, \quad \ln q_{\mathrm{e}}=\ln K_{\mathrm{F}}+\frac{1}{n \ln C_{\mathrm{e}}}$ where $q_{\mathrm{e}}\left(\mathrm{mg} \mathrm{g}^{-1}\right)$ is the equilibrium metal uptake, $C_{\mathrm{e}}\left(\mathrm{mg} \mathrm{l}^{-1}\right)$ is the concentration of metal in solution at equilibrium, $q_{\max }\left(\mathrm{mg} \mathrm{g}^{-1}\right)$ is the 
maximum uptake by the biomass and $b, K_{\mathrm{F}}$ and $n$ are the constants corresponding to the respective isotherms.

Isotherms were calculated for total cadmium removed after $24 \mathrm{~h}$ of exposure.

\subsection{Extraction and detection of non-protein sulfhydryl-group-rich compounds in crude extracts}

Cells from cultures not exposed to cadmium and exposed to different concentrations of this metal were collected by centrifugation ( $3500 \times g$ for $15 \mathrm{~min}$ ). The cell pellet was resuspended in $0.2 \mathrm{~N} \mathrm{HCl}$ and the cells were homogenized with an ultrasonic cell disrupter for 4 min at $150 \mathrm{~W}$ and $14 \mu \mathrm{m}$ of amplitude. Cellular debris was removed by centrifugation at $13,000 \times g$ for $15 \mathrm{~min}$ at $4{ }^{\circ} \mathrm{C}$. Non-protein sulfhydryl-group-rich compounds were determined in these acid crude extracts by the method of Ellman [19]. An aliquot of $400 \mu \mathrm{l}$ of the acid extract was mixed with $700 \mu \mathrm{l}$ of a solution containing $10 \mathrm{mM}$ dithiobis-nitrobenzoic acid (DTNB, Ellman reagent) and $1 \mathrm{mM}$ EDTA in $0.5 \mathrm{M}$ sodium phosphate buffer, $\mathrm{pH} 7.5$. After $10 \mathrm{~min}$ of reaction in darkness, the absorbance was recorded at $412 \mathrm{~nm}$. Values were corrected for the absorbance of the reagents and of the extracts. Glutathione (GSH) was used as a suitable calibrating substance for quantifying the sulfhydryl groups.

\subsection{Statistical analysis}

Data were analyzed using the statistical program SPSS 14 (SPSS Iberica, Madrid, Spain). The results were tested by one-way analysis of variance (ANOVA) $(p<0.01)$, and the mean values of the treatments were compared by Dunnett's test.

\section{Results}

\subsection{Growth}

Cultures of $D$. salina exposed to different cadmium concentrations showed an inhibition in their growth as a consequence of the toxic effect of the metal. Fig. 1 represents the cellular density during $96 \mathrm{~h}$ of culture for each concentration assayed. At $24 \mathrm{~h}$ of culture significant differences between the different cultures were not observed in the growth. However, an inhibition in the growth was observed at $48 \mathrm{~h}$ of metal exposure. In the cultures exposed to $5 \mathrm{mg} \mathrm{Cd} \mathrm{l}^{-1}$ (the smaller assayed concentration), at $48 \mathrm{~h}$ of culture, an inhibitory effect of cadmium was observed, with a inhibition percentage of $8.6 \%$ in comparison to the control cultures. At $72 \mathrm{~h}$ of culture, cultures with cadmium concentrations of 80 and $100 \mathrm{mg} \mathrm{l}^{-1}$ hardly grew, and in those with the highest cadmium concentration assayed $\left(120 \mathrm{mg} \mathrm{l}^{-1}\right)$ total inhibition of growth was observed from $48 \mathrm{~h}$ of culture. The cellular density of the cultures with greater cadmium concentrations hardly varied throughout the 72 and $96 \mathrm{~h}$ of culture (with a cellular density of $50.0 \times 10^{4}$ cell $\mathrm{ml}^{-1}$ ). As can be observed in the figure, the inhibition was proportional to cadmium concentration: as cadmium concentration increased in the medium, growth 
decreased. This indicates that the effect of cadmium on the growth of the microalga depended on the metal concentration in the medium. According to the ANOVA and Dunnett's test there is a significant effect of this metal on the growth of the microalga $D$. salina. After these test it is possible to infer that the toxic effect of the cadmium in the growth of the microalga, in the conditions of culture assayed, was: control $<5<10<20<30<40<60<80<100<120$. From this sequence it is possible to deduce that the lowest observed effect concentration (LOEC) was $5 \mathrm{mg} \mathrm{Cd} \mathrm{l-1}^{-1}$, not being observed in this assay the no observed effect concentration (NOEC) or it

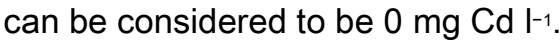

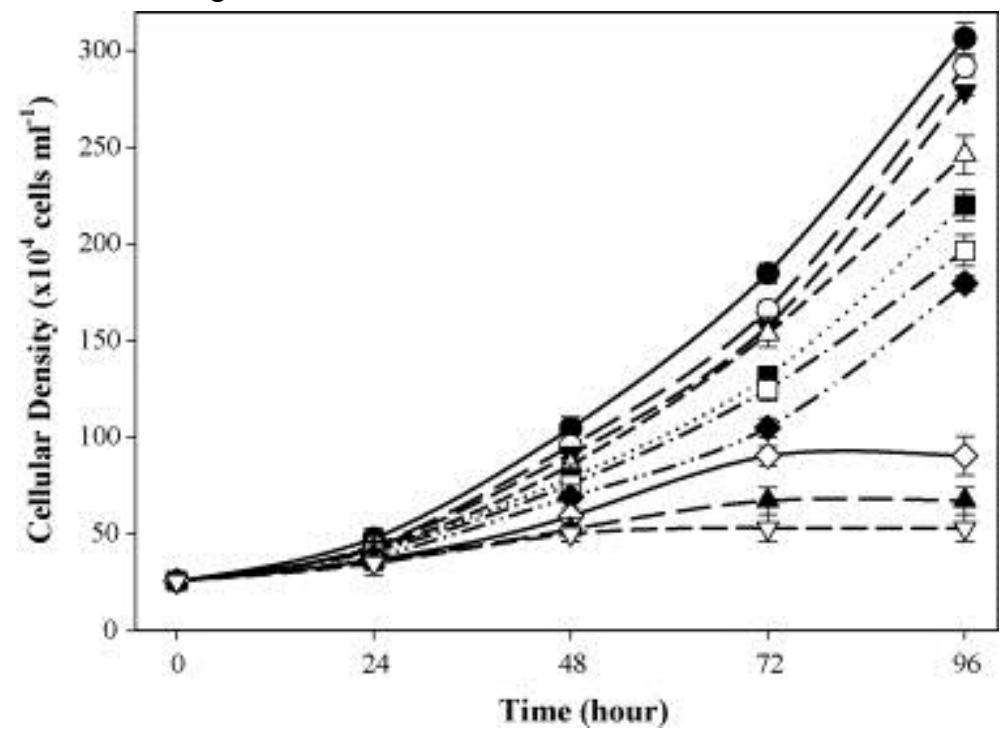

Fig. 1.

Effect of cadmium on growth of Dunaliella salina cells. Data represent the means of three sample

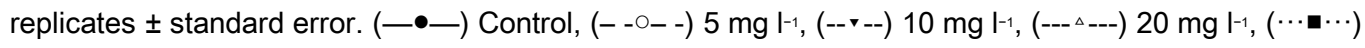

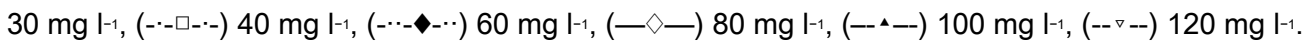

The toxic effect of cadmium also can be measured directly through the parameter EC50. The value obtained for $D$. salina was estimated as $48.9 \mathrm{mg} \mathrm{l}^{-1}$ of cadmium after $96 \mathrm{~h}$ of exposure to this metal. The $95 \%$ confidence interval for EC50 ranges from 43.1 to $55.5 \mathrm{mg} \mathrm{l}^{-1}$ of cadmium.

\subsection{Cadmium removed}

\subsubsection{Total cadmium removed}

Removal of cadmium was observed in all assayed concentrations from $24 \mathrm{~h}$ of culture. Fig. 2 represents the quantity of cadmium removed by this microalga depending on the concentration of cadmium in medium and throughout the time of culture. The total removed cadmium by the cells increased as the metal concentration increased in all the assayed concentrations. Nevertheless, there was only an increase in the first $24 \mathrm{~h}$ of culture. In the cultures with the lowest assayed concentrations (5 and $10 \mathrm{mg} \mathrm{Cd} \mathrm{l-1}^{-1}$ scarcely any metal removal was observed, with a maximum quantity of cadmium removed of $5.9 \times 10^{-10}$ and 
$1.0 \times 10^{-9} \mathrm{mg} \mathrm{Cd}$ cell-1, respectively. In the remaining cultures, the quantity of cadmium removed

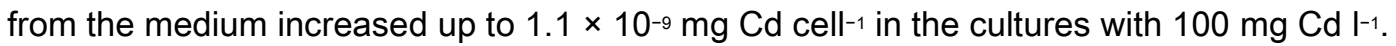

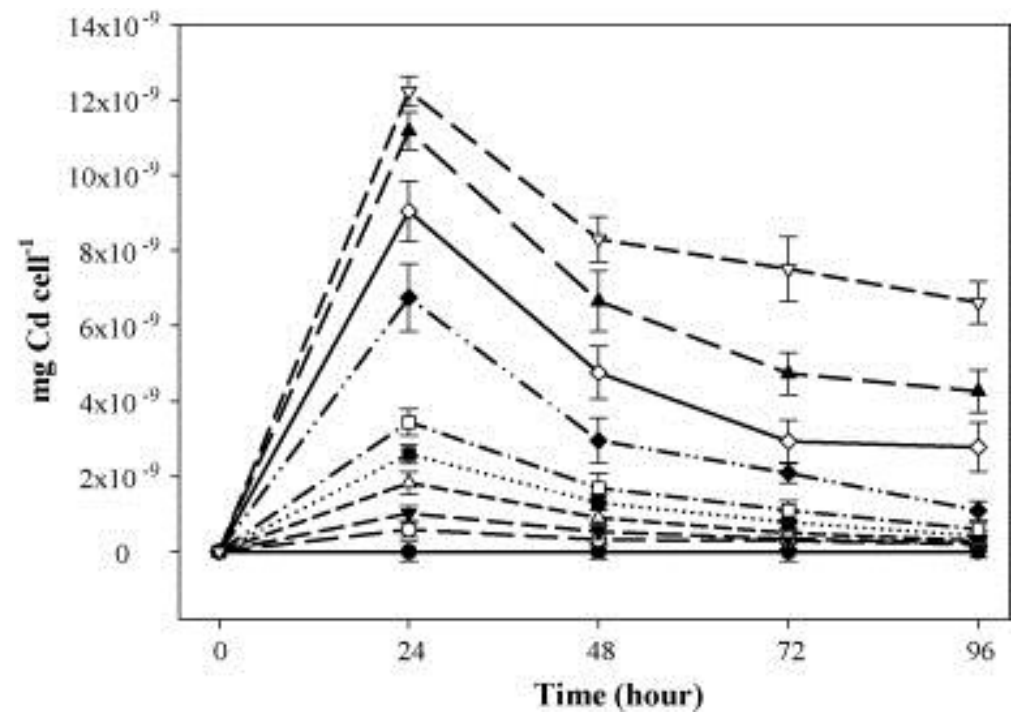

Fig. 2.

Evolution of total cadmium removed by cells of $D$. salina exposed to different cadmium concentrations. Data represent the means of three sample replicates \pm standard error. (-•-) Control, (-- - - ) $5 \mathrm{mg} \mathrm{l-1}$,

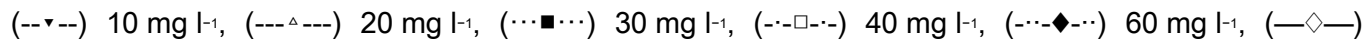
$80 \mathrm{mg} \mathrm{l-1},\left(--^{---)} 100 \mathrm{mg} \mathrm{l-1},(--\nabla--) 120 \mathrm{mg} \mathrm{l-1}\right.$.

The greater quantity of metal removed by cell, took place in the cultures exposed to $120 \mathrm{mg} \mathrm{Cd} \mathrm{l}^{-1}$ reaching a concentration of $1.2 \times 10^{-8} \mathrm{mg} \mathrm{Cd} \mathrm{cell}^{-1}$ at $24 \mathrm{~h}$ of culture (Fig. 2). Later, at $48 \mathrm{~h}$ of culture, a descent is produced in the quantity of total removed cadmium in all the concentrations assayed. In this way, the cadmium removal capacity of the cells of $D$. salina depended directly on the metal quantity that is present in the medium and of the time of exposure.

\subsubsection{Intracellular cadmium}

Once the cells of the microalga contact with cadmium, part of the cadmium removed by the cells is adsorbed on the cellular surface and another part accumulates intracellularly. Fig. 3 represents the quantity of cadmium removed intracellularly for the cells of $D$. salina. In the first $48 \mathrm{~h}$ of culture, the intracellular cadmium increased in each of the assayed concentrations. In cultures with the smaller concentrations of metal in the medium $\left(5,10,20\right.$ and $\left.30 \mathrm{mg} \mathrm{Cd} \mathrm{l-1}^{-1}\right)$ the quantity of cadmium removed intracellularly increased linearly with time of culture. In these cultures, after this rapid period of bioaccumulation $(48 \mathrm{~h})$, the concentration of bioaccumulated

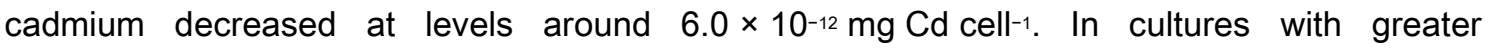
concentrations of cadmium $\left(40,60,80,100\right.$ and $\left.120 \mathrm{mg} \mathrm{l}^{-1}\right)$, this linear increase is produced only during the first $48 \mathrm{~h}$ of culture; from this point, cadmium removed intracellularly diminished at values of $6.0 \times 10^{-12} \mathrm{mg} \mathrm{Cd}$ cell-1. This decrease in the quantity of intracellular cadmium is proportional to the cadmium concentration in the medium, the maximum decrease being in cultures with 100 and $120 \mathrm{mg} \mathrm{Cd} \mathrm{I-1}^{-1}$. The maximum of intracellular cadmium quantity was 
detected in the cultures exposed to $60 \mathrm{mg} \mathrm{Cd} \mathrm{l}^{-1}$ after $48 \mathrm{~h}$ of culture, reaching a concentration of $1.5 \times 10^{-10} \mathrm{mg} \mathrm{Cd}$ cell-1. In spite of this, the quantity of cadmium removed intracellularly in the

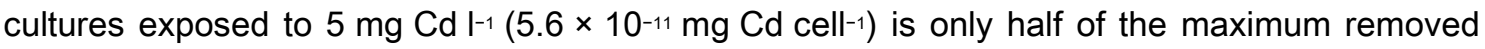
quantity.

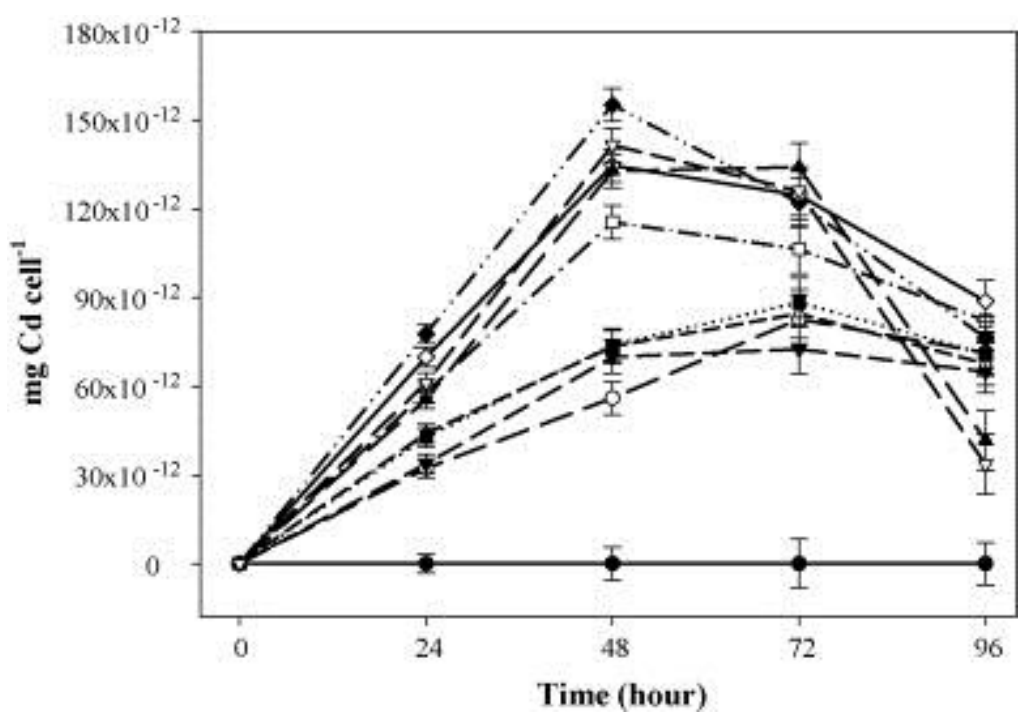

Fig. 3.

Evolution of intracellular cadmium removed by cells of $D$. salina exposed to different cadmium concentrations. Data represent the means of three sample replicates \pm standard error. ( $-\longrightarrow$ ) Control,

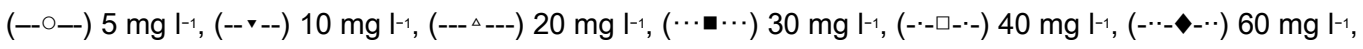
$(-\diamond-) 80 \mathrm{mg} \mathrm{l}^{-1},\left(--^{--}\right) 100 \mathrm{mg} \mathrm{l-1,},(----) 120 \mathrm{mg} \mathrm{l-1.}$

\subsubsection{Bioadsorbed cadmium}

Fig. 4 represents the quantity of cadmium removed by bioadsorption to the surface of the cells of $D$. salina. For each of the assayed concentrations, kinetics similar to the one that was observed in the total cadmium removed was obtained. The quantity of cadmium bioadsorbed increased in all the cultures during the first $24 \mathrm{~h}$, diminishing later. That way, when the metal concentration in the medium increased, increased the quantity of the bioabsorbed metal to the cellular surface (just like the total cadmium removed). Therefore, the largest quantity of cadmium removed by bioadsorption is produced at $24 \mathrm{~h}$ in the cultures with $120 \mathrm{mg} \mathrm{Cd} \mathrm{l}^{-1}$, with $1.2 \times 10^{-8} \mathrm{mg} \mathrm{Cd}$ cell-1 that is 22 times the quantity measured in the cultures exposed to

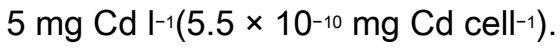




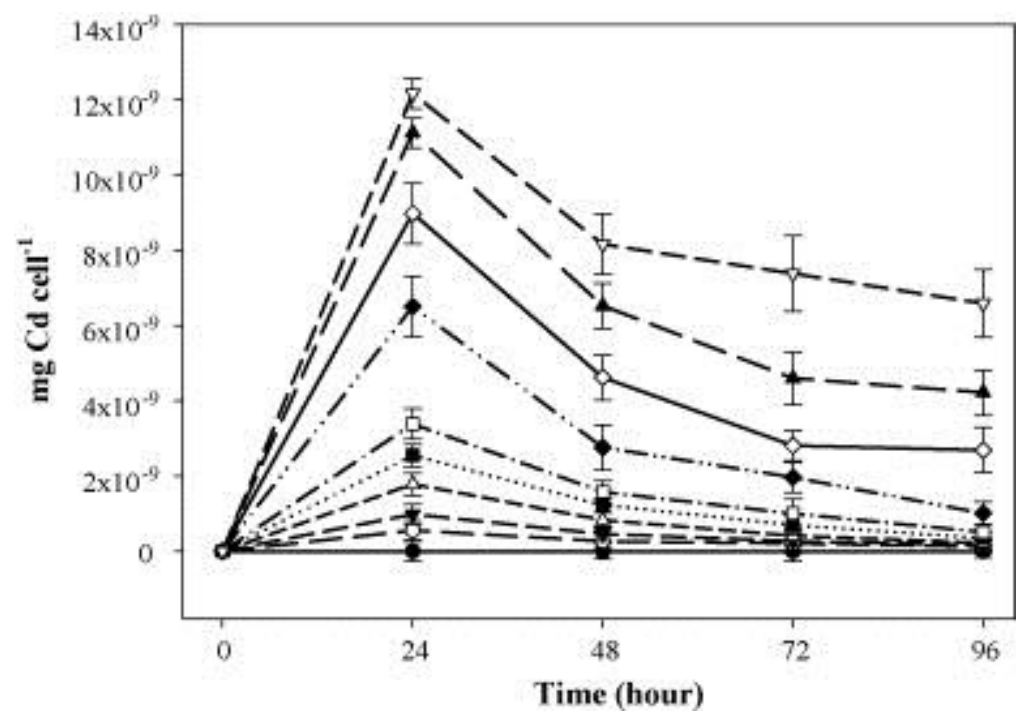

Fig. 4.

Evolution of bioadsorbed cadmium removed by cells of $D$. salina exposed to different cadmium concentrations. Data represent the means of three sample replicates \pm standard error. (- - ) Control,

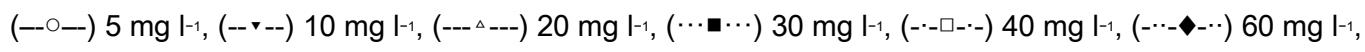
$(-\diamond-) 80 \mathrm{mg} \mathrm{l}^{-1},\left(--^{--}\right) 100 \mathrm{mg} \mathrm{l}^{-1},(--\nabla--) 120 \mathrm{mg} \mathrm{l}^{-1}$.

After analyzing the quantity of cadmium removed in the two compartments (bioadsorbed and intracellular), and the total cadmium removed, it can be observed that the quantity of cadmium removed intracellularly is much smaller than the quantity of bioadsorbed cadmium at the end of the process. Hence, the cultures exposed to $120 \mathrm{mg} \mathrm{Cd} \mathrm{l}^{-1}$ contain a concentration of bioadsorbed cadmium that exceeded in 200 times the concentration of intracellular cadmium at $96 \mathrm{~h}$ of culture. Nevertheless, in the cultures exposed to the smaller concentration assayed (5 mg Cd l-1) the intracellular cadmium only was exceeded 1.7 times (Table 1). Therefore, increases in the metal concentration in the medium increase the difference between the quantity of bioadsorbed cadmium and the intracellular cadmium.

Table 1.

Concentration of cadmium extracted by cells of the microalga Dunaliella salina exposed to different cadmium concentrations after $96 \mathrm{~h}$ of culture. Values in brackets are the percentage of cadmium removed in relation to the amount of initial cadmium added to medium (intracellular cadmium and bioadsorbed cadmium represent percentages in relation to total cadmium removed). Data represent the means of three sample replicates \pm standard error.

\begin{tabular}{|c|c|c|c|}
\hline $\begin{array}{l}\text { Initial cadmium concentrations } \\
\text { added to the cultures }\left(\mathrm{mg} \mathrm{l}^{-1}\right)\end{array}$ & $\begin{array}{l}\text { Total cadmium } \\
\text { removed }\left(\mathrm{mg} \mathrm{l}^{-1}\right)\end{array}$ & $\begin{array}{l}\text { Intracellular } \\
\text { cadmium }\left(\mathrm{mg} \mathrm{l}^{-1}\right)\end{array}$ & $\begin{array}{l}\text { Bioadsorbed } \\
\text { cadmium }\left(\mathrm{mg} \mathrm{l}^{-1}\right)\end{array}$ \\
\hline Control & $0.00 \pm 0.00(0.0)$ & $0.00 \pm 0.00(0.0)$ & $0.00 \pm 0.00(0.0)$ \\
\hline 5 & $0.56 \pm 0.05(11.3)$ & $0.21 \pm 0.07(37.5)$ & $0.35 \pm 0.08(62.5)$ \\
\hline 10 & $0.62 \pm 0.08(6.2)$ & $0.18 \pm 0.08(29.0)$ & $0.44 \pm 0.02(71.0)$ \\
\hline 20 & $0.72 \pm 0.07(3.6)$ & $0.17 \pm 0.04(23.6)$ & $0.55 \pm 0.09(76.4)$ \\
\hline 30 & $0.92 \pm 0.05(3.1)$ & $0.16 \pm 0.03(17.4)$ & $0.76 \pm 0.06(82.6)$ \\
\hline 40 & $1.16 \pm 0.03(2.9)$ & $0.16 \pm 0.09(13.8)$ & $1.00 \pm 0.07(86.2)$ \\
\hline 60 & $1.94 \pm 0.09(3.2)$ & $0.14 \pm 0.08(7.2)$ & $1.80 \pm 0.04(92.8)$ \\
\hline 80 & $2.51 \pm 0.08$ & $0.08 \pm 0.08$ & $2.43 \pm 0.06(96.8)$ \\
\hline
\end{tabular}




\begin{tabular}{|l|l|l|l|}
$\begin{array}{l}\text { Initial cadmium concentrations } \\
\text { added to the cultures }\left(\mathrm{mg} \mathrm{l}^{-1}\right)\end{array}$ & $\begin{array}{l}\text { Total cadmium } \\
\text { removed }\left(\mathrm{mg} \mathrm{l}^{-1}\right)\end{array}$ & $\begin{array}{l}\text { Intracellular } \\
\text { cadmium }\left(\mathrm{mg} \mathrm{l}^{-1}\right)\end{array}$ & $\begin{array}{l}\text { Bioadsorbed } \\
\text { cadmium }\left(\mathrm{mg} \mathrm{l}^{-1}\right)\end{array}$ \\
\hline 100 & $2.86 \pm 0.06(2.8)$ & $0.03 \pm 0.05(1.0)$ & $2.83 \pm 0.05(99.0)$ \\
\hline 120 & $3.50 \pm 0.08(2.9)$ & $0.02 \pm 0.09(0.6)$ & $3.48 \pm 0.03(99.4)$
\end{tabular}

\subsubsection{Percentage of cadmium removed in relation to the added cadmium}

The percentage of cadmium removed by the cells after $96 \mathrm{~h}$ of culture in relation to the added cadmium is indicated in Table 1 . The percentage of total cadmium removed by the cells decreased as the metal concentration in the medium increased. The greater percentage of cadmium removed was obtained in cultures exposed to $5 \mathrm{mg} \mathrm{Cd} \mathrm{l}^{-1}$ at $96 \mathrm{~h}$ of culture, removing $11.3 \%$ of the initial cadmium added. Nevertheless, for the rest of concentrations assayed the quantity of total cadmium removed becomes stable in values near to $3 \%$ (with the exception of the culture of $10 \mathrm{mg} \mathrm{Cd} \mathrm{l}^{-1}$ with a value of $6.2 \%$ ). That is, from the concentration of $20 \mathrm{mg} \mathrm{Cd} \mathrm{l}^{-1}$, the percentage of cadmium removed did not vary when increasing the concentration of metal, remaining practically constant along the time of culture.

\subsubsection{Concentration of cadmium removed by each culture}

The cadmium concentration ( $\mu \mathrm{g} \mathrm{l}^{-1}$ ) extracted from the culture by the cells of $D$. salinawas greater in the cultures exposed to the higher concentrations of the metal (Table 1). The maximum concentration of metal was extracted in the cultures exposed to $120 \mathrm{mg} \mathrm{Cd} \mathrm{l}^{-1}$ after $96 \mathrm{~h}$ of culture with a total concentration of $3.5 \mathrm{mg} \mathrm{Cd} \mathrm{l}^{-1}$, of which most of metal is bioadsorbed to the cellular surface, reaching a concentration of $3.48 \mathrm{mg} \mathrm{Cd} \mathrm{l-1}^{-1}$. This result (in which practically all the metal removed was in bioadsorbed form) was observed for each one of the concentrations assayed. Thus, the proportion of cadmium bioadsorbed present in the cells of the microalga was higher than intracellular cadmium in all cultures ( Table 1). The cultures with a concentration of $5 \mathrm{mg} \mathrm{Cd} \mathrm{I-1}^{-1}$ presented the greater percentage of metal removed from medium. However, this \% of metal removed supposed the minor value of quantity of metal removed as compared with its initial concentration. Whereas, the culture that presented one of the smaller value of $\%$ of metal removed $\left(120 \mathrm{mg} \mathrm{Cd} \mathrm{I-1}^{-1}\right)$ presented the greater quantity of metal removed as compared with its initial concentration (Table 1). In this way, the intracellular cadmium quantity present in the cells of $D$. salina always was smaller than the bioadsorbed cadmium quantity. The intracellular cadmium quantity and the percentage of cadmium removed diminished as the concentration of metal increased in the medium ( Table 1).

\subsection{Biosorption studies}

Isotherms for the biosorption of cadmium by live biomass of $D$. salina after $24 \mathrm{~h}$ of exposure are shown in Fig. 5. The Langmuir isotherm provides good information $\left(R^{2}=0.9887\right)$ about the cadmium uptake by $D$. salina. The maximum uptake as derived from Langmuir was $52 \mathrm{mg} \mathrm{Cd} \mathrm{g-}$ 1. 

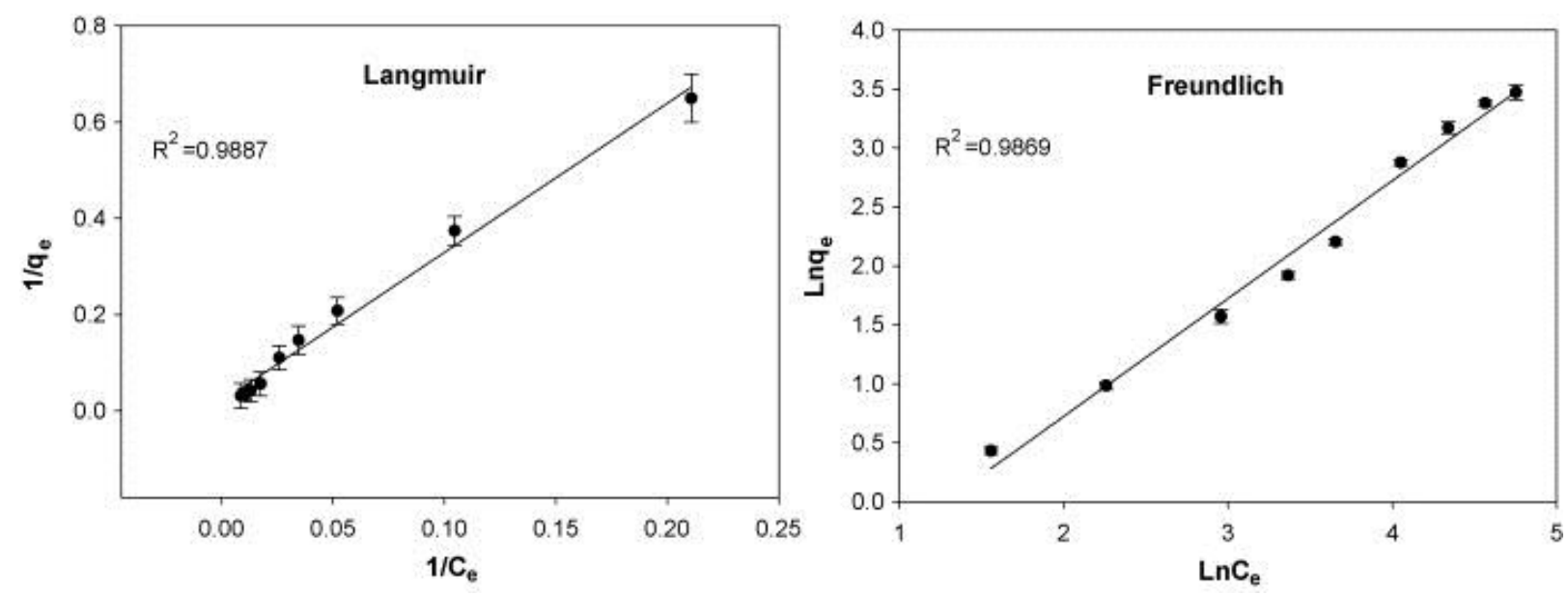

Fig. 5 .

Langmuir and Freundlich isotherms for the sorption of cadmium by living cells of $D$. salina after $24 \mathrm{~h}$ of exposure. Data represent the means of three sample replicates \pm standard error.

The experimental data also were well correlated to the Freundlich equation with $R^{2}=0.987$. The values of $K_{\mathrm{F}}$ and $n$ obtained from this model were 0.28 and 1 , respectively.

\subsection{Time course of sulfhydryl groups}

Fig. 6 shows the evolution of the sulfhydryl groups $(-\mathrm{SH})$ throughout the time in the different cultures of $D$. salina exposed to different concentrations of cadmium and in cultures without metal addition. This evolution showed that the concentration of these groups ( $\mu \mathrm{mol}-\mathrm{SH} \mathrm{cell}^{-1}$ ) was proportional to the initial concentration of cadmium in the medium ( Fig. 5). In the control cultures the quantity of sulfhydryl groups remained constant throughout the time of culture. Unlike this, in the first $48 \mathrm{~h}$ of culture, an increased in the concentration of sulfhydryl groups is produced when increased the cadmium concentration in the medium. Thus, the highest values of - $\mathrm{SH}$ groups were reached in the cultures exposed to the greater concentrations of cadmium

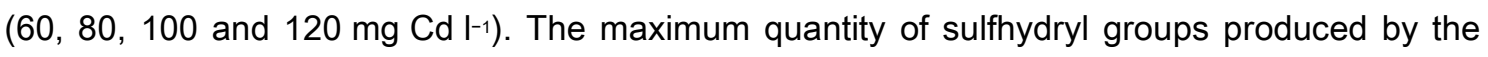
cells of $D$. salina was reached in the cultures exposed to $120 \mathrm{mg} \mathrm{Cd} \mathrm{l}^{-1}$ with a value of $3.9 \times 10^{-}$ ${ }^{9} \mu \mathrm{mol}-\mathrm{SH}$ cell ${ }^{-1}$ after the first $48 \mathrm{~h}$ of culture. This value exceeded in four times the concentration reached in the cultures exposed to $5 \mathrm{mg} \mathrm{Cd} \mathrm{l}^{-1}\left(9.4 \times 10^{-10} \mu \mathrm{mol}-\mathrm{SH}\right.$ cell-1)$)$. After the first $48 \mathrm{~h}$ of culture, in all the metal concentrations assayed, a gradual reduction in the concentration of sulfhydryl groups took place until that a value around $1.3 \times 10^{-9} \mu \mathrm{mol}-\mathrm{SH}$ cell1 at $96 \mathrm{~h}$ of culture was reached. The sulfhydryl groups quantity depends directly on the amount of metal presents in the cell interior. In agreement with this, analysing the contents in sulfhydryl groups ( Fig. 5) and the quantity of cadmium removed intracellularly ( Fig. 3), it can be observed that both parameters present a similar evolution. That is, they presented a maximum value at $48 \mathrm{~h}$ of culture, and from here on, these parameters diminished in each metal concentration assayed. 


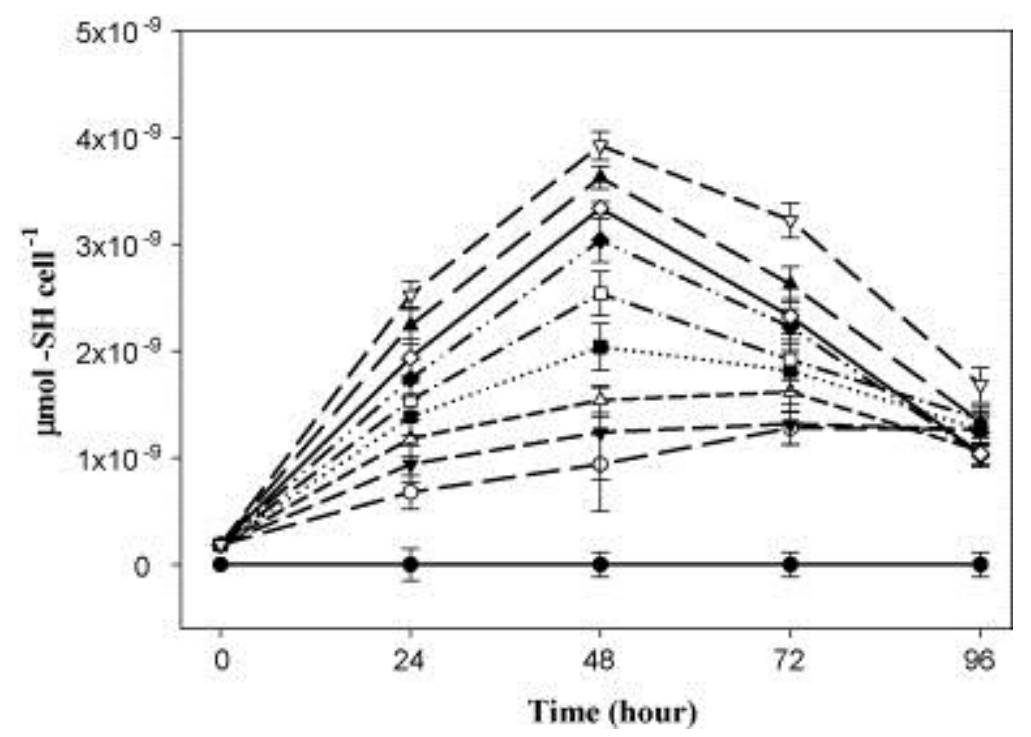

Fig. 6.

Production of sulfhydryl groups in cells of $D$. salina exposed to different cadmium concentrations. Data

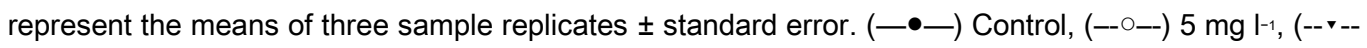

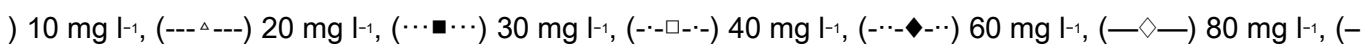
---) $100 \mathrm{mg} \mathrm{l}-1,(--\nabla-)) 120 \mathrm{mg} \mathrm{l}-1$.

\section{Discussion}

The effect of metals on growth has been studied in many microorganisms. These studies indicate that there is a wide interval in the sensibility to cadmium. In microalgae, the effect of this metal on growth depends of the microalgae species and the metal concentration in the medium. Hence, the growth of the species Chlorococcum sp. and Tetraselmis gracilis is inhibited with concentrations of 2.5-3.0 and $5.0 \mathrm{mg} \mathrm{l}^{-1}$, respectively [20], [21] and [22], which indicates a high resistance to the cadmium. On the contrary, among the most sensitive are Asterionella formosa and Chlorella saccharophila whose growth is inhibited with concentrations of 0.01 and $0.11 \mu \mathrm{g} \mathrm{l}^{-1}$, respectively [23] and [24].

Results obtained with the present study demonstrate that $D$. salina can be included inside the group of microalgae species more tolerant to cadmium. In addition, inside this group of tolerant species, $D$. salina is one of the most tolerant species to this metal. Its inclusion in this group is because, although all concentrations of metal assayed produced a reduction in its growth, growth existed in the cultures exposed to higher concentrations of metal just as $40 \mathrm{mg} \mathrm{Cd} \mathrm{I-}$ 1 (always a minor growth than the control), along the time of culture ( Fig. 1). The capacity of resistance of a microalga to the toxic action of a metal also can be observed analyzing its value of EC50 for that metal. After $96 \mathrm{~h}$ of exposure to cadmium, the EC50 obtained for the microalga /sochrisis galbana was $0.74 \mathrm{mg} \mathrm{Cd} \mathrm{l-1}^{-1}$ [25]. These differences in the sensibility to the cadmium are produced even inside species of the same genus, in this way the same occurs between Tetrase/mis gracilis with an EC50 of $1.8 \mathrm{mg} \mathrm{Cd} \mathrm{I-1}^{-122]}$ and Tetraselmis suecica with an EC50 of $7.9 \mathrm{mg} \mathrm{Cd}^{-1}$ [26]. The EC50 value for the growth obtained for $D$. salina after $96 \mathrm{~h}$ of exposure to cadmium was $48.9 \mathrm{mg} \mathrm{Cd} \mathrm{I}^{-1}$. Also, the EC10 and EC20 obtained statistically by 
means of the regression function were 11.9 and $20.7 \mathrm{mg} \mathrm{Cd} \mathrm{l}^{-1}$, respectively. Therefore, $D$. salina can be included in the group of microalgal species most tolerant of cadmium due to the very high value of EC50 that it possesses and for this reason, it was necessary to use so high cadmium concentrations in this assay. Nevertheless, this comparison is in a general way, since, to be able to compare the grade of toxicity for two species (or even for the same species), the culture has to be carried out under the same conditions (culture medium, initial cellular density, etc.), which is difficult, because the species are cultivated with very varied conditions in the bibliography. An example of this is that, Visviki and Rachlin, working also with $D$. salina, obtained an EC50 of only $0.5 \mathrm{mg} \mathrm{Cd} \mathrm{l-1}^{-1}$ after $96 \mathrm{~h}$ of exposure [27].

Numerous arguments have been proposed to explain why the cadmium affects the growth of microalgae. The toxicity of this metal is its negative influence on the cellular enzymatic systems. This is due to the substitution that the cadmium exercises on other metallic ions in metalloenzymes (principally $\mathrm{Zn}, \mathrm{Cu}$ and $\mathrm{Ca}$ ) and for its great affinity for biological structures that contain -SH groups, like proteins and enzymes, causing the inhibition of growth, photosynthesis, respiration rate and other cellular processes [28]. Also, there are toxicological studies that suggest that cadmium can behave like a radical. In this way, cadmium can react with the molecular oxygen producing reactivate oxygen species (ROS) [29]. These ROS produce toxic effects such as peroxidation of lipidic membranes, depolymerisation of polysaccharides, denatured of proteins and damages in the DNA [30].

In spite of these effects, $D$. salina showed a high tolerance in the assayed conditions what would allow its use in the cadmium removal from polluted mediums. There is a great variety of water treatment processes polluted by metals, the majority of which include physical-chemical of oxide-reduction processes. Nevertheless, the biological methods have demonstrated their great effectiveness in the metal removal and also their use would avoid the toxic effects of the chemical reagents. The aquatic organisms, especially microalgae, are characterized by their capacity in the incorporation of metals and in their later accumulation intracellularly, provoking an increase in the intracellular concentration of the metal with regard to the cellular exterior [29]. Studies made with different microalgae species show that the effectiveness in metal removal depends not only on the algal species, but also depends on the metal. A study made with some algae species to compare their ability in the removal of five toxic metals during $30 \mathrm{~min}$ of exposure revealed thatScenedesmus quadricaudaretired more than $90 \%$ of the initial concentration of $\mathrm{Cd}$, whereas the cyanobacterium Mastigocladus laminosus was the most effective in removing $\mathrm{Al}(>90 \%)$, being less effective in cadmium removal. The initial concentration of these metals was $1 \mathrm{mg} \mathrm{l}^{-1}$ [31] The Gram-negative bacterium Sphingomonas paucimobilis has higher cadmium removal capacity with a efficiency of $84 \%$ from a solution containing $50 \mathrm{mg} \mathrm{Cd} \mathrm{l}^{-1}$ [32] Therefore, the selection of a suitable organism can potentially increase the removal of a specific contaminated water metal. Pérez-Rama et al. [26] exposed the microalga Tetrase/mis suecica to a cadmium concentration of $6 \mathrm{mg} \mathrm{l}^{-1}$ and the percentage of cadmium removed from the culture was $59.6 \%$ after 6 days; whereas, in our study, cells of $D$. salina exposed to a concentration of $5 \mathrm{mg} \mathrm{l}^{-1}$, in the same culture conditions as Tetraselmis, 
removed only $11.3 \%$ of cadmium after $96 \mathrm{~h}$ ( Table 1). In the cultures exposed to higher cadmium concentrations, the percentage of cadmium removed by the cells of $D$. salina was smaller. This demonstrates that the microalga $T$. suecica is an excellent candidate for the treatment of waters contaminated by cadmium. Nevertheless, on the contrary, $D$. salina does not have good properties for this purpose owing to the low levels of metal removed from the medium, in spite of its high resistance to the toxicity of this metal.

Microalgae are capable of carrying out this process of metal removal from the environment, and two of the principal mechanisms to achieve this are the union of metals to cellular surfaces (bioadsorption) and intracellular accumulation (bioaccumulation). The results of the present work showed that during $96 \mathrm{~h}$ of exposure to cadmium, the cells of $D$. salina accumulated the metal in bioadsorbed form to the cellular surface, being less the cadmium removed intracellularly ( Table 1). This coincides with the studies with cyanobacteria and microalgae of Parker et al. and Mehta et al. [33] and [34], but it does not coincide with other studies with microalgae species, since, according to Torres et al. [35] in cultures of Phaeodactylum tricornutum and Pérez-Rama et al. [26] with Tetraselmis suecica, the metal quantity that these microalgae incorporate by means of passive mechanisms of bioadsorption into the cellular surface is much lower than the quantity of metal removed intracellularly. This low capacity to uptake cadmium intracellularly is the reason for which this microalga has less possibilities of being used as a living biomass to remove metal.

Both the Freundlich and Langmuir adsorption models were suitable for describing the short-term biosorption of cadmium by $D$. salina cells. The results obtained from these models indicated that this microalga showed low cadmium uptake capacity. The maximum capacity obtained for $C$. vulgaris was $111.1 \mathrm{mg} \mathrm{g}^{-1}$ and the values of $K_{\mathrm{F}}$ and $n$ were 8.23 and 2.05 , respectively [36]. For immobilized cells of $C$. reinhardtii the values obtained were $88.6,15.27$ and $2.91 \mathrm{mg} \mathrm{g}^{-1}$ [37]. Whereas for $D$. salinathe values obtained were only $52,0.28$ and $1 \mathrm{mg} \mathrm{g}^{-1}$, respectively. However, when this capacity is compared with that of other organisms (not microalgae), $D$. salina showed better parameters. For example, the maximum adsorption capacity for the macrophyte $H$. verticillata was $15 \mathrm{mg} \mathrm{g}^{-1} \underline{[38]}, 26.5 \mathrm{mg} \mathrm{g}^{-1}$ for the heavy metal resistant bacterium $B$. circulans strain EB1 [39] and $31.6 \mathrm{mg} \mathrm{g}^{-1}$ for $\mathrm{NaOH}$-treated cells of Rhizopus oryzae [40]. This constitutes one more evidence of that microalga biomass has a higher heavy metal biosorption capacity and offers considerable potential for biosorbent applications.

All metal concentrations assayed showed a correspondence between the cadmium removed intracellularly and the total cadmium removed. Both parameters started with an increment in the quantity of metal removed in the first hours of culture, and next, a descent in this quantity in all the metal concentrations assayed. Therefore, at $96 \mathrm{~h}$ of culture, almost all of the total cadmium removed by the cells of $D$. salina is in bioadsorbed form in the cellular wall, and only a minimum

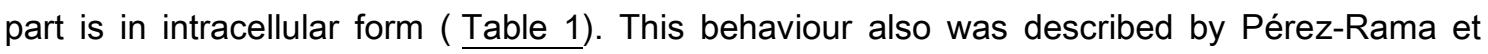
al. [26] in cultures with Tetrase/mis suecica where, in cultures exposed to high concentration of cadmium (45 mg l-1), $60.1 \%$ of the total cadmium removed was bioadsorbed. 
With the data obtained in this study, the cells of $D$. salina removed low quantities of metal from the medium (mainly by bioadsorption). In this way, this microalga should have some protective system against the cadmium toxicity that prevents the metal accumulation to the interior of cell. One of those possible mechanisms is the development of a number of routes and modes for excreting metals [41]. A more common method in eukaryotes is either active or passive excretion of metals [42]. Metal efflux is considered to be an active mechanism requiring energy expenditure. Nevertheless, Jin et al. [43] suggested that $\mathrm{Ni}^{+2}$ efflux in some strains of Scenedesmus acutus occurred by passive diffusion in the dark after they were transferred to $\mathrm{Ni}$-free medium. Verma and Singh [44] showed the presence of an energy-dependent $\mathrm{Cu}$-efflux system in a Cu-resistant mutant of Nostoc calcicola. Active efflux transport systems would provide an effective detoxification mechanism. Metals can be selectively and actively excreted against concentration gradients by permeases and the $\mathrm{Na} / \mathrm{K}$ and $\mathrm{Ca}$ ATPases [45]. Others strategies for decrease metal influx are the reduction of the permeability for a metal ion [46] and modifications of the cell wall [47].

Apart from the different mechanisms that cells have to prevent the accumulation of metal in their interior, there are also mechanisms for which cells can accumulate metals intracellularly without their being toxic for the cell. One of these mechanisms of tolerance is the union to intracellular metal-complexing ligands. These compounds are low molecular weight metal-binding peptides, rich in cysteine, classified as sulfhydryl groups or thiols. In microalgae, the most frequent types are GSH and phytochelatins (PCs). The levels of sulfhydryl groups are directly related to the levels of intracellular cadmium removed. In this study, all metal concentrations assayed showed a correspondence between the sulfhydryl group levels and the cadmium removed intracellularly. Both parameters presented, in the first $48 \mathrm{~h}$ of culture, an increment of their levels to, subsequently, descent at 72 and $96 \mathrm{~h}$ of culture, which suggests that they present a mechanism of control that synthesizes the concentration of phytochelatins necessary to sequestrate the intracellular cadmium. Torres et al. [48] found that $P h$. tricornutum cells bound $60 \%$ of cellular cadmium as cadmium-binding complexes, composed principally by phytochelatins. Also, metal analysis showed that about $87 \%$ of the cadmium in $T$. suecica was bound by these phytochelatins [49]. Our results indicate that the cells of $D$. salina are capable of bioadsorbing cadmium to their cellular surface but they scarcely are able of bioaccumulating cadmium intracellularly which would allow for better metal removal from the medium when alive biomass is used, because living cells have a markedly higher capacity to remove metal than nonliving cells [48], [26] and [32]. In fact, the biggest percentage of cadmium removed was only $11.3 \%$ at initial cadmium concentration of $5 \mathrm{mg} \mathrm{l}^{-1}$. Consequently, the microalga $D$. salina can be included among the most tolerant species to cadmium; nevertheless, it is not a good candidate to be used in processes of cadmium removal from contaminated seawaters.

\section{Conclusions}


$D$. salina can be included in the group of microalgal species most tolerant to cadmium due to the high value of EC50 that it possesses $\left(48.9 \mathrm{mg} \mathrm{Cd} \mathrm{l}^{-1}\right.$ at $96 \mathrm{~h}$ of culture). The greater percentage of cadmium removed was obtained in cultures exposed to $5 \mathrm{mg} \mathrm{Cd} \mathrm{l}^{-1}$ at $96 \mathrm{~h}$, removing only $11.3 \%$ of the added cadmium. In all the cultures, the quantity of cadmium removed intracellularly was much lower than the bioadsorbed quantity and was proportional to the sulfhydryl group levels. Both of the Langmuir and Freundlich models give good fits to the adsorption isotherms. The maximum adsorption capacity after $24 \mathrm{~h}$ was only $52 \mathrm{mg} \mathrm{Cd} \mathrm{g}^{-1}$. Owing to the low levels of cadmium removed and in spite of being very tolerant to cadmium, $D$. salina is not a good candidate among microalgae to be used in processes of cadmium removal from contaminated seawaters.

\section{Acknowledgments}

This work was carried out with the support of the Plan Nacional de I + D (Ref: REM 20000458HIB). S. Folgar holds a Fellowship Award from the Universidade da Coruña. We thank Servicios Generales de Apoyo a la Investigación from Universidade da Coruña.

\section{References}

[1]

J. Fentem, M. Balls

Replacement of fish in ecotoxicology testing: use of bacteria, other lower organism and fish cells in vitro M. Richardson (Ed.), Ecotoxicology Monitoring, VCH, Weinheim (1993), pp. 71-81

[2] O.P. Dhankher, Y. Li, B.P. Rosen, J. Shi, D. Salt, J.F. Senecoff, N.A. Sashti, R.B. Meagher Engineering tolerance and hyperaccumulation of arsenic in plants by combining arsenate reductase and gamma-glutamylcysteine synthetase expression

Nat. Biotechnol., 20 (2002), pp. 1140-1145

[3]

G.E. Walsh

Principles of toxicity testing with marine unicellular algae

Environ. Toxicol. Chem., 7 (1988), pp. 979-987

[4]

OECD/OCDE, Freshwater Alga and Cyanobacteria, Growth Inhibition Test, OECD Guidelines for the Testing of Chemicals (201). Adopted 23 March 2006, Geneva, 2006.

[5] Inhibitory effects of heavy metals on growth and photosynthesis of three freshwater microalgae Fish. Sci., 60 (1994), pp. 379-384

[6] 
T.C. Wang, J.C. Weissman, G. Ramesh, R. Varadarajan, J.R. Benemann

Heavy metal binding and removal by Phormidium

Bull. Environ. Contam. Toxicol., 60 (1998), pp. 739-744

[7]

\section{L.E. Macaskie}

The application of biotechnology of the treatment of wastes from the nuclear fuel cycle: biodegradation and bioaccumulation as a means of treating radionuclide containing streams

Crit. Rev. Biotechnol., 11 (1991), pp. 41-112

[8]

G. Bertin, D. Averbeck

Cadmium: cellular effects, modifications of biomolecules, modulation of DNA repair and genotoxic consequences (a review)

Biochimie, 88 (2006), pp. 1549-1559

[9]

R.W. Furness, P.S. Rainbow

Heavy Metals in the Marine Environment

CRC Press, Inc., Boca Raton, FL (1990)

[10]

E. Pinto, T.C.S. Sigaud-Kutner, M.A.S. Leitao, O.K. Okamoto, D. Morse, P. Colepicolo

Heavy metal-induced oxidative stress in algae

J. Phycol., 39 (2003), pp. 1008-1018

[11]

W. Gekeler, E. Grill, E.-L. Winnnacker, M.H. Zenk

Algae sequester heavy metals via synthesis of phytochelatin complexes

Arch. Microbiol., 150 (1988), pp. 197-202

E. Torres, A. Cid, P. Fidalgo, C. Herrero, J. Abalde

Long-chain class III metallothioneins as a mechanism of cadmium tolerance in the marine diatom Phaeodactylum tricornutum Bohlin

Aquat. Toxicol., 39 (1997), pp. 231-246

[13]

E. Torricelli, G. Gorbi, B. Pawlik-Skowronska, L.S. Di Toppi, M.G. Corradi

Cadmium tolerance, cysteine and thiol peptide levels in wild type and chromium-tolerant strains of Scenedesmus acutus (Chlorophyceae)

Aquat. Toxicol., 68 (2004), pp. 315-323 


\section{Pérez-Rama, E. Torres, J. Abalde}

Composition and production of thiol constituents induced by cadmium in the marine microalga Tetraselmis suecica

Environ. Toxicol. Chem., 25 (2006), pp. 128-136

\section{[15]}

D.J. Bonin, M.R. Droop, S.Y. Maestrini, M.-C. Bonin

Physiological features of six micro-algae to be used as indicators of seawater quality

Cryptogamie Algol., 7 (1986), pp. 23-83

[16]

A.R. Cowan, P.D. Rose, L.G. Horne

Dunaliella salina: a model system for studying the response of plant cells to stress

J. Exp. Bot., 43 (1992), pp. 1535-1547

[17]

J. Fábregas, C. Herrero, J. Abalde, R. Liaño, B. Cabezas

Biomass production and biochemical variability of the marine microalga Dunaliella tertiolecta (Butcher) with high nutrient concentrations

Aquaculture, 53 (1986), pp. 187-199

J.L. Stauber, T.M. Florence

The influence of iron on copper toxicity to the marine diatom Nitzschia closterium (Ehrenberg) W. Smith Aquat. Toxicol., 6 (1985), pp. 297-305

G.L. Ellman

Tissue sulfhydryl groups

Arch. Biochem. Biophys., 82 (1959), pp. 70-77

J.R. Cain, D.C. Paschal, C.M. Hayden

Toxicity and bioaccumulation of cadmium in the colonial green alga Scenedesmus obliquus Arch. Environ. Contam. Toxicol., 9 (1980), pp. 9-16

[21]

P.V. Devi Prasad, P.S. Devi Prasad

Effect of cadmium, lead and nickel on three freshwater green algae

Water Air Soil Pollut., 17 (1982), pp. 263-268

[22]

O.K. Okamoto, C.S. Asana, E. Aidar, P. Colepicolo 
Effects of cadmium on growth and superoxide dismutase activity of the marine microalga Tetraselmis gracilis (Prasinophyceae)

J. Phycol., 32 (1996), pp. 74-79

[23]

H.L. Conway

Sorption of arsenic and cadmium and their effects on growth, micronutrient utilization, and photosynthetic pigment composition of Asterionella formosa

J. Fish. Res. Bd. Can., 35 (1978), pp. 286-294

J.W. Rachlin, B. Warkentine, T.E. Jensen

The growth responses of Chlorella saccharophila, Navicula inserta and Nitzschia closterium to selected concentrations of cadmium

Bull. Torrey Bot. Club, 109 (1982), pp. 129-135

[25]

C.K. Yap, A. Ismail, H. Omar, S.G. Tan

Toxicities and tolerances of $\mathrm{Cd}, \mathrm{Cu}, \mathrm{Pb}$ and $\mathrm{Zn}$ in a primary producer (Isochrysis galbana) and in a primary consumer (Perna viridis)

Environ. Int., 29 (2004), pp. 1097-1104

[26]

M. Pérez-Rama, J. Abalde, C. Herrero, E. Torres

Cadmium removal by living cells of the marine microalga Tetraselmis suecica

Bioresour. Technol., 8 (2002), pp. 265-270

[27]

I. Visviki, D. Rachlin

Acute and chronic effect exposure of Dunaliella salina and Chlamydomonas bullosa to copper and cadmium: effects on ultrastructure

Arch. Environ. Contam. Toxicol., 26 (1994), pp. 154-162

[28]

J. Vymazal

Toxicity and accumulation of cadmium with respect of algae and cyanobacteria: a review

Toxicol. Assess., 2 (1987), pp. 387-415

[29]

R.H. Reed, G.M. Gadd

Metal tolerance in eukaryotic and prokaryotic algae

A.J. Shaw (Ed.), Heavy Metal Tolerance in Plants: Evolutionary Aspects, CRC Press, Inc., Boca Ratón, FL (1990), pp. 105-118 
[30]

B. Halliwell, J.M.C. Gutteridge

Free Radicals in Biology and Medicine

Oxford University Press, New York (1991)

[31]

J.C. Radway, E.W. Wilde, M.J. Whitaker, J.C. Weissman

Screening of algal strains for metal removal capabilities

J. Appl. Phycol., 13 (2001), pp. 451-455

[32]

J. Tangaromsuk, P. Pokethitiyook, M. Kruatrachue, E.S. Upatham

Cadmium biosorption by Sphingomonas paucimobilis biomass

Bioresour. Technol., 85 (2002), pp. 103-105

[33]

D.L. Parker, L.C. Rai, N. Mallick, P.K. Rai, H.D. Kumar

Effect of cellular metabolism and viability on metal ion accumulation by cultured biomass from a bloom of the cyanobacterium Microcystis aeruginosa

Appl. Environ. Microbiol., 64 (1998), pp. 1545-1547

S.K. Mehta, B.N. Tripathi, J.P. Gaur

Influence of $\mathrm{pH}$, culture age and cations on adsorption and uptake of $\mathrm{Ni}$ by Chlorella vulgaris

Eur. J. Protistol., 36 (2000), pp. 443-450

[35]

E. Torres, A. Cid, C. Herrero, J. Abalde

Effect of cadmium on growth, ATP content, carbon fixation and ultrastructure in the marine diatom Phaeodactylum tricornutum Bohlin

Water Air Soil Pollut., 117 (2000), pp. 1-14

[36]

Z. Aksu

Equilibrium and kinetic modelling of cadmium(II) biosorption by C. vulgaris in a batch system: effect of temperature

Sep. Purif. Technol., 21 (2001), pp. 285-294

[37]

G. Bayramoglu, I. Tuzun, G. Celik, M. Yilmaz, M.Y. Arica

Biosorption of mercury(II), cadmium(II) and lead(II) ions from aqueous system by microalgae Chlamydomonas reinhardtii immobilized in alginate beads

Int. J. Miner. Process, 81 (2006), pp. 35-43 
[38]

S. Bunluesin, M. Kruatrachue, P. Pokethitiyook, E.S. Upatham, G.R. Lanza

Batch and continuous packed column studies of cadmium biosorption by Hydrilla verticillata biomass

J. Biosci. Bioeng., 103 (2007), pp. 509-513

[39]

E.I. Yilmaz, N.Y. Ensari

Cadmium biosorption by Bacillus circulans strain EB1

World J. Microbiol. Biotechnol., 21 (2005), pp. 777-779

[40]

W.Y. Baik, J.H. Bae, K.M. Cho, W. Hartmeier

Biosorption of heavy metals using whole mold mycelia and parts thereof

Bioresour. Technol., 81 (2002), pp. 167-170

[41]

E. Morelli, G. Scarano, M. Ganni, L. Nannicini, A. Serriti

Copper binding ability of the extracellular organic material released by Skeletonema costatum

Chem. Spec. Bioavail., 1 (1989), pp. 71-76

[42]

H.-B. Xue, L. Sigg

Binding of $\mathrm{Cu}(\mathrm{II})$ to algae in a metal buffer

Water Res., 24 (1990), pp. 1129-1136

[43]

X. Jin, D.J. Kushner, C. Nalewajko

Nickel uptake and release in nickel-resistant and sensitive strains of Scenedesmus acutus $f$. alternans (Chlorophyceae)

Environ. Exp. Bot., 36 (1996), pp. 401-411

S.K. Verma, H.N. Singh

Evidence for energy-dependent copper efflux as a mechanism of $\mathrm{Cu} 2+$ resistance in the cyanobacterium Nostoc calcicola

FEMS Microbiol. Lett., 84 (1991), pp. 291-294

[45]

A.Z. Mason, K.D. Jenkins

Metal detoxification in aquatic organisms

A. Tessier, D.R. Turner (Eds.), Metal Speciation and Bioavailability in Aquatic Systems, John Wiley \& Sons Ltd., California (1995), pp. 479-608

[46] 
L.C. Rai, A.K. Singh, N. Mallick

Studies on photosynthesis, the associated electron transport system and some physiological variables of Chlorella vulgaris under heavy metal stress

J. Plant Physiol., 137 (1991), pp. 419-424

[47]

M.R. Twiss, C. Nalewajko

Influence of phosphorus nutrition on copper toxicity to three strains of Scenedesmus acutus (Chlorophyceae)

J. Phycol., 28 (1992), pp. 291-298

[48]

E. Torres, A. Cid, C. Herrero, J. Abalde

Removal of cadmium ions by the marine diatom Phaeodactylum tricornutum Bohlin accumulation and long-term kinetics of uptake

Bioresour. Technol., 63 (1998), pp. 213-220

[49]

M. Pérez-Rama, C. Herrero, J. Abalde, E. Torres

Class III metallothioneins in response to cadmium toxicity in the marine microalga Tetraselmis suecica (Kylin) Butch

Environ. Toxicol. Chem., 20 (2001), pp. 2061-2066

Corresponding author at: Departamento de Biología Celular y Molecular, Laboratorio de Microbiología, Facultad de Ciencias, Universidade da Coruña, Campus da Zapateira s/n, 15071 La Coruña, Spain. Tel.: +34 981 167000; fax: +34 981167065.

Copyright (C) 2008 Elsevier B.V. All rights reserved 